\title{
Microsatellite loci in the tetraploid spined loach, Cobitis biwae, and cross-species amplification in four related species
}

\author{
O. Jablonska ${ }^{1 *}$, A. Marín ${ }^{2 *}$, K. Kowalewska ${ }^{1}$, T. Fujimoto ${ }^{2}$ and K. Arai ${ }^{2}$ \\ ${ }^{1}$ University of Warmia and Mazury in Olsztyn, Department of Zoology, \\ Oczapowskiego, Olsztyn, Poland \\ ${ }^{2}$ Hokkaido University, Graduate School of Fisheries Sciences, Minato, \\ Hakodate, Hokkaido, Japan \\ *These authors contributed equally to this study. \\ Corresponding author: O. Jablonska \\ E-mail: olga.jablonska@uwm.edu.pl
}

Genet. Mol. Res. 15 (3): gmr.15039027

Received July 25, 2016

Accepted August 22, 2016

Published September 23, 2016

DOI http://dx.doi.org/10.4238/gmr.15039027

Copyright (C 2016 The Authors. This is an open-access article distributed under the terms of the Creative Commons Attribution ShareAlike (CC BY-SA) 4.0 License.

\begin{abstract}
Fifteen microsatellite loci were identified in the tetraploid spined loach, Cobitis biwae (Teleostei: Cobitidae). Among these, 14 were polymorphic (5-31 alleles) and showed moderate to high cross-species amplification transferability in four related species, Cobitis matsubarai, Cobitis taenia, Misgurnus anguillicaudatus, and Misgurnus fossilis. The loci, described herein, will be useful for population genetics, phylogeny, parentage analysis, and detection of hybridization among Cobitis species.
\end{abstract}

Key words: Hybrid; Polyploid; SSRS; Enriched library 


\section{INTRODUCTION}

Spined loaches of the genus Cobitis (Cobitidae, Cypriniformes) are fresh water fishes, widely distributed in Europe and Asia. They are species complex that result from the natural process of hybridization, unisexual reproduction, and polyploidization (Saitoh et al., 2010; Janko et al., 2012; Choleva et al., 2014). The genus Cobitis has attracted interest owing to its unusually complicated and poorly recognized genome constitution, which is a consequence of hybridization and genome duplication events (Bohlen and Rab, 2001).

The isolation of nuclear markers, such as microsatellite markers is helpful for tracing hybridization events in Cobitis complexes, and has been previously conducted in some European Cobitis species (De Gelas et al., 2008). However, to date, no microsatellite marker has been described for Cobitis distributed around Asia.

One of the Japanese Cobitis complexes is $C$. biwae, which comprises the diploid and tetraploid forms having 48 and 96 chromosomes, respectively (Kobayashi, 1976; Ueno and Ojima, 1976). The diploid form is distributed throughout the northern and central Honshu and on the Pacific slope of Shikoku Islands, whereas the tetraploid form occurs in the western Honshu and Shikoku and its distribution is limited to the Seto Inland Sea slope (Kimizuka and Kobayashi, 1983; Kitagawa et al., 2003). C. biwae could be an appropriate model, not only for zoogeographic studies (Bohlen and Rab, 2001), but also for evolutionary process or recent tetraploidization due to natural gene duplication (Kusunoki et al., 1994; Kitagawa et al., 2003). In the present study, we report the first set of microsatellite loci for C. biwae and the levels of their polymorphism among tetraploid individuals. Additionally, all the loci were tested for cross-species amplification in four other related Cobitidae species.

\section{MATERIAL AND METHODS}

Fifty-eight tetraploid C. biwae individuals captured from the Kamo River, Takehara City, Hiroshima Prefecture, Japan were used in this study. Ploidy status of all the fishes was determined by measuring the DNA content of somatic cells collected from caudal-fin using flow cytometry (Fujimoto et al., 2007). Tetraploidy was determined by the DNA content measured with a Ploidy Analyzer (Partec GmbH, Münster, Germany) using DNA content in the diploid wild type Misgurnus anguillicaudatus as the reference (2.53 pg/nucleus; Zhang and Arai, 1996). The DNA content of C. biwae (5.75 $\pm 0.15 \mathrm{pg} /$ nucleus) was in the range of other tetraploid Cobitis (Vasil'ev et al., 1999; Juchno et al., 2010). Genomic DNA was isolated from the dorsal fin clip following the standard phenol-chloroform protocol. Microsatellite enriched library was constructed using the DNA isolated from one individual by magnetic beads hybridization selection protocol (Glenn and Schable, 2005). Briefly, approximately 5 mg DNA was digested with HaeIII (Roche, Basel, Switzerland). After enzymatic digestion, the digested DNA was size selected (500-1.500 bp) using QIAquick gel extraction kit (Qiagen, Hilden, Germany). The recovered DNA was dephosphorylated and ligated to SNX linker (Hamilton et al., 1999) and then amplified by PCR using SNX forward primer. A hybridization step was performed for the enrichment library construction. Purified linker ligated DNA was hybridized to biotinylated (CAT) ${ }_{8}$ and $(\mathrm{GAT})_{8}$ probes (hybridization temperatures were about 5 degrees below the Tm of each probe). Subsequently, the hybridized DNA was captured using streptavidin-coated magnetic beads (Dynabeads ${ }^{\circledR}$ Magnetic Beads; Life Technologies, Carlsbad, CA, USA) and subjected to stringent washes to remove the unhybridized DNA. The

Genetics and Molecular Research 15 (3): gmr.15039027 
recovered DNA was amplified by PCR using the SNX forward primer (initial denaturation for $2 \mathrm{~min}$ at $92^{\circ} \mathrm{C}$, followed by 25 cycles of denaturation for $45 \mathrm{~s}$ at $94^{\circ} \mathrm{C}$, annealing for $1 \mathrm{~min}$ at $62^{\circ} \mathrm{C}$, extension for $1 \mathrm{~min}$ at $72^{\circ} \mathrm{C}$, and a final extension for $30 \mathrm{~min}$ at $72^{\circ} \mathrm{C}$ ). Amplified fragments were ligated into pCR4-Topo vector and transformed into TOP10 One Shot chemical competent Escherichia coli cells (Life Technologies). A total of 96 colonies were screened by PCR using M13(-20)-F and M13-R primers, and sequenced using the BigDye terminator v3.1 Cycle Sequencing Kit (Applied Biosystems, Waltham, MA, USA) with M13(20) forward primer on an ABI PRISM 3130XL Genetic Analyzer (Applied Biosystems). Primers, containing sufficient flanking regions, were designed for 35 microsatellite containing sequences using the Primer Premier 6.0 software. All putative microsatellite loci were PCR screened in four $C$. biwae individuals. Finally, 21 primer pairs were selected based on agarose gel visualization of the PCR products for further screening by fragment analysis sequence using M13-tailed primers. PCR was performed as described by Morishima et al. (2008). Briefly, 100 ng template DNA was amplified in a final volume of $10 \mu \mathrm{L}$ reaction mix containing $200 \mu \mathrm{M}$ dNTPs, 0.3 pmol M13-tailed forward primer, 3.0 pmol reverse primer, 3.0 pmol fluorescencelabeled M13 primer, and 0.5 U Taq polymerase (TaKaRa Bio Inc., Kusatsu, Shiga, Japan); thermocycling conditions were as follows: initial denaturation for $3 \mathrm{~min}$ at $95^{\circ} \mathrm{C}$, followed by 35 cycles of denaturation for $30 \mathrm{~s}$ at $95^{\circ} \mathrm{C}$, annealing for $30 \mathrm{~s}$ at $56^{\circ} \mathrm{C}$, extension for 30 $\mathrm{s}$ at $72^{\circ} \mathrm{C}$, and a final extension for $45 \mathrm{~min}$ at $72^{\circ} \mathrm{C}$. PCR products were sequenced using formamide with GeneScan LIZ-500 size standard (Applied Biosystems). The GeneMapper 3.7 software (Applied Biosystems) was used for allele scoring.

ATETRA 1.2 (Van Puyvelde et al., 2010), which was developed to analyze tetraploid microsatellite data, was used to estimate the number of alleles $\left(N_{\mathrm{A}}\right)$, expected heterozygosity $\left(H_{\mathrm{E}}\right)$, and Shannon-Wiener diversity indices $\left(H^{\prime}\right)$.

\section{RESULTS AND DISCUSSION}

After fragment analysis, 15 microsatellite loci resulted in unambiguous peak patterns. These loci were used for genotyping 58 tetraploid individuals of $C$. biwae. Although only tri-nucleotide biotinylated probes were used for constructing the libraries, a high rate of di-nucleotide CA/GT repeat motif was found $(73 \%)$. This finding is consistent with that of a previous study, where di-nucleotide microsatellite motifs were the most abundant form of microsatellites in vertebrates and arthropods (Tóth et al., 2000). Overall, 14 polymorphic primer sets were used, and revealed up to four alleles per locus per individual, confirming tetraploidy. The $N_{\mathrm{A}}$ per locus ranged from 4 (Cobi26) to 31 (Cobi31), with a mean of 11.4 (Table 1).

The $H_{\mathrm{E}}$ ranged from 0.388 to 0.947 (mean $H_{\mathrm{E}}=0.693$ ), and the $H^{\prime}$ ranged from 0.811 to 3.160 (mean $H^{\prime}=1.672$ ). The loci exhibited moderate to high levels of polymorphism (4 to 31 alleles). The transferability of the microsatellite loci, reported herein, was evaluated in four related species: Cobitis matsubarai (Kawatana River, Shimonoseki City, Yamaguchi Prefecture, Japan), Cobitis taenia (Lake Leginski, Warmia-Masuria Province, Poland), M. anguillicaudatus (Kunebetsu River, Nanae Town, Hokkaido Prefecture, Japan), and Misgurnus fossilis (Wieprz River, Lubelskie Province, Poland) (Table 2). Moderate (M. anguillicaudatus and $M$. fossilis) to high (C. matsubarai and C. taenia) levels of cross-species amplification were observed. The new microsatellite loci described in this study will be useful for population genetics, phylogeny, parentage analysis, and hybrid detection among Cobitis species.

Genetics and Molecular Research 15 (3): gmr.15039027 
Table 1. Genetic characterization of 15 microsatellite loci developed for Cobitis biwae.

\begin{tabular}{|c|c|c|c|c|c|c|c|c|c|}
\hline Locus & Primers $\left(5^{\prime} \rightarrow 3^{\prime}\right)$ & Dye & Repeat motif & Size (bp) & $N_{\mathrm{A}}$ & $\mathrm{N}$ & $H_{\mathrm{E}}$ & $H^{\prime}$ & Accession No. \\
\hline Cobi5 & $\begin{array}{l}\text { F: CATCAGACCAACCTGTAAGG } \\
\text { R: TCATCCCTACACTCATCC }\end{array}$ & VIC & $(\mathrm{A})_{11}$ & $267-300$ & 12 & 48 & 0.842 & 2.079 & KC573043 \\
\hline Cobi6 & $\begin{array}{l}\text { F: GGGTTCAATTTCCAGAGAA } \\
\text { R: TTTGAACAGCGTGCAGTG }\end{array}$ & NED & $(\mathrm{CA})_{14}$ & $204-499$ & 13 & 58 & 0.489 & 1.242 & KC573044 \\
\hline Cobil3 & $\begin{array}{l}\text { F: GGTGTGACTTCATTTCG } \\
\text { R: TACAGTACTTGTACCTCAAAGG }\end{array}$ & NED & $(\mathrm{GT})_{15}$ & $206-308$ & 15 & 54 & 0.770 & 1.906 & KC573045 \\
\hline Cobil7 & $\begin{array}{l}\text { F: ATCAGTGTCATAGGCACA } \\
\text { R: GGACTCAATCATGGTTACAC }\end{array}$ & VIC & $(\mathrm{CA})_{12}$ & $198-271$ & 22 & 50 & 0.907 & 2.651 & KC573046 \\
\hline Cobil9 & $\begin{array}{l}\text { F: GAGGTGACAGGTGAGTGA } \\
\text { R: CTAATTTGCACCCATTTGGT }\end{array}$ & PET & $(\mathrm{CA})_{6}$ & $232-261$ & 6 & 56 & 0.415 & 0.875 & KC573047 \\
\hline Cobi21 & $\begin{array}{l}\text { F: TTTCAAGTCCAAGAACAGTC } \\
\text { R: AGGGTGATAACTGAGAATGA }\end{array}$ & VIC & $(\mathrm{GT})_{5}$ & $217-287$ & 6 & 54 & 0.388 & 0.811 & KC573048 \\
\hline Cobi22 & $\begin{array}{l}\text { F: ATCCAGCAGGTTCTGTCT } \\
\text { R: AAGATTCAGATGGCAAGAGA }\end{array}$ & VIC & $(\mathrm{CT})_{11}$ & $178-188$ & 6 & 57 & 0.703 & 1.419 & KC573049 \\
\hline Cobi24 & $\begin{array}{l}\text { F: AGAACGCGAAATTGGCAGT } \\
\text { R: TCTCTCTACCTCATTCGCT }\end{array}$ & VIC & $(\mathrm{GT})_{15}$ & $247-283$ & 8 & 48 & 0.812 & 1.804 & KC573050 \\
\hline Cobi26 & $\begin{array}{l}\text { F: AATCATCCAACAGGTGTCTGC } \\
\text { R: GGTGGATGTGAATGTGACT }\end{array}$ & VIC & ${ }_{2}^{(\mathrm{GAT})_{6} \ldots(\mathrm{A})_{1}}$ & $180-294$ & 4 & 58 & 0.645 & 1.162 & KC573055 \\
\hline Cobi27 & $\begin{array}{l}\text { F: GCACAGCCATGATACCTTA } \\
\text { R: AACGGATGCTTGACAGAC }\end{array}$ & VIC & $(\mathrm{GT})_{13}$ & $252-415$ & 14 & 51 & 0.819 & 2.004 & KC573051 \\
\hline Cobi30 & $\begin{array}{l}\text { F: GACAGAGACCTTTATTTCTG } \\
\text { R: AGATGTCACGATGCATTTGT }\end{array}$ & VIC & $(\mathrm{AC})_{5}(\mathrm{AG})_{9}$ & $106-328$ & 7 & 45 & 0.749 & 1.498 & KC573052 \\
\hline Cobi31 & $\begin{array}{l}\text { F: CCAGAGTCTTGCCAGGTA } \\
\text { R: CAGGAAGATTGGACGCTAT }\end{array}$ & NED & $(\mathrm{GT})_{10}$ & $250-372$ & 31 & 58 & 0.947 & 3.160 & KC573053 \\
\hline Cobi32 & $\begin{array}{l}\text { F: GAGATGATCACTAGAATACATGAGG } \\
\text { R: AGAGAAGATCTAGAACTGAG }\end{array}$ & PET & $(\mathrm{T})_{12}$ & $120-179$ & 5 & 58 & 0.423 & 0.882 & KC573057 \\
\hline Cobi35 & $\begin{array}{l}\text { F: ATACTGGGACTATGAAGCC } \\
\text { R: GACATCACAACGGCATTC }\end{array}$ & VIC & $(\mathrm{CAT}) 9$ & $256-390$ & 11 & 56 & 0.800 & 1.909 & KC573054 \\
\hline Cobi28 & $\begin{array}{l}\text { F: CCAACTACTCCATATCTTCTTC } \\
\text { R: GTGGCGGAGGAACAGTA }\end{array}$ & VIC & $(\mathrm{CT})_{6}(\mathrm{GT})_{3}$ & $300-328$ & 2 & 50 & - & - & KC573056 \\
\hline
\end{tabular}

F: forward, R: reverse primer sequences, bp: allele size range, $N_{\mathrm{A}}$ : number of alleles, $\mathrm{N}$ : number of genotyped individuals, $H_{\mathrm{E}}$ : mean expected heterozygosity $H^{\prime}$ : Shannon-Wiener diversity indices.

Table 2. Cross-species amplification results of Cobitis biwae microsatellite markers in four related species: Cobitis matsubarai, Cobitis taenia, Misgurnus anguillicaudatus, and Misgurnus fossilis.

\begin{tabular}{|c|c|c|c|c|c|c|c|c|c|c|c|c|}
\hline \multirow[t]{2}{*}{ Locus } & \multicolumn{3}{|c|}{ C. matsubarai } & \multicolumn{3}{|c|}{ C. taenia } & \multicolumn{3}{|c|}{ M. anguillicaudatus } & \multicolumn{3}{|c|}{ M. fossilis } \\
\hline & $\mathrm{N}$ & $N_{\mathrm{A}}$ & Size range (bp) & $\mathrm{N}$ & $N_{\mathrm{A}}$ & Size range (bp) & $\mathrm{N}$ & $N_{\mathrm{A}}$ & Size range (bp) & $\mathrm{N}$ & $N_{\mathrm{A}}$ & Size range (bp) \\
\hline Cobi5 & 25 & 6 & $270-280$ & 7 & 2 & $272-273$ & 8 & 2 & $265-273$ & 5 & 1 & 281 \\
\hline Cobi6 & 25 & 4 & $442-444$ & 7 & 8 & $157-250$ & 7 & 1 & 105 & - & - & $\mathrm{X}$ \\
\hline Cobil3 & - & - & $\mathrm{O}$ & 5 & 1 & 239 & 7 & 1 & 252 & - & - & $\mathrm{X}$ \\
\hline Cobil7 & 24 & 9 & $225-457$ & 7 & 1 & 199 & - & - & $\mathrm{X}$ & - & - & $\mathrm{X}$ \\
\hline Cobil9 & 26 & 6 & $233-267$ & 7 & 1 & 252 & 8 & 2 & $265-273$ & - & - & $\mathrm{X}$ \\
\hline Cobi21 & 25 & 6 & $232-241$ & 7 & 2 & $216-234$ & 7 & 2 & $119-326$ & 3 & 3 & $132-240$ \\
\hline Cobi22 & 27 & 5 & $173-255$ & 8 & 2 & $172-186$ & 8 & 1 & 174 & 5 & 3 & $314-474$ \\
\hline Cobi24 & - & - & $\mathrm{O}$ & - & - & $\mathrm{X}$ & - & - & $\mathrm{X}$ & 2 & 1 & 307 \\
\hline Cobi26 & 22 & 3 & 190-199 & 6 & 2 & $181-195$ & 8 & 2 & $116-193$ & 5 & 3 & 194-239 \\
\hline Cobi27 & - & - & $\mathrm{O}$ & - & - & $\mathrm{O}$ & - & - & $\mathrm{X}$ & - & - & $\mathrm{X}$ \\
\hline Cobi30 & - & - & $\mathrm{X}$ & 7 & 4 & $145-190$ & - & - & $\mathrm{X}$ & 5 & 3 & $154-161$ \\
\hline Cobi31 & 26 & 4 & $240-248$ & 8 & 2 & $242-244$ & - & - & $\mathrm{X}$ & 3 & 3 & $188-248$ \\
\hline Cobi32 & - & - & $\mathrm{X}$ & 6 & 1 & 170 & - & - & $\mathrm{X}$ & - & - & $\mathrm{X}$ \\
\hline Cobi35 & 10 & 4 & 176-352 & - & - & $\mathrm{X}$ & 8 & 1 & 173 & - & - & $\mathrm{X}$ \\
\hline Cobi28 & 4 & 2 & $305-307$ & 5 & 3 & $313-319$ & - & - & $\mathrm{X}$ & 3 & 4 & $256-482$ \\
\hline
\end{tabular}

$\mathrm{N}$ : number of individuals, $N_{\mathrm{A}}$ : number of alleles, bp: allele size range, $\mathrm{X}$ : no amplification, $\mathrm{O}$ : multiple bands pattern or product of unexpected size.

\section{Conflicts of interest}

The authors declare no conflict of interest.

Genetics and Molecular Research 15 (3): gmr.15039027 


\section{ACKNOWLEDGMENTS}

Research supported by the Japan Society for the Promotion of Science (JSPS), including Postdoctoral Fellowship for Foreign Researchers (O. Jablonska, \#2012FY; \#PE12052) and the Poland-Japan Research Cooperative Program in 2015 to 2016 FY. Moreover, research supported in part by the University of Warmia and Mazury in Olsztyn, Poland (project \#12.620.020300). The authors would like to thank T. Umino (Hiroshima University, Higashi-Hiroshima, Japan) for providing C. biwae samples, H. Sakai (National Fisheries University, Shimonoseki, Japan) for C. matsubarai samples, as well as A. Boron and D. Juchno (University of Warmia and Mazury in Olsztyn, Poland) for providing M. fossilis and C. taenia samples.

\section{REFERENCES}

Bohlen J and Rab P (2001). Species and hybrid richness in spined loaches of the genus Cobitis L. (Teleostei: Cobitidae) with a checklist of European forms and suggestions for conservation. J. Fish Biol. 59a: 75-89. http://dx.doi. org/10.1111/j.1095-8649.2001.tb01380.x

Choleva L, Musilova Z, Kohoutova-Sediva A, Paces J, et al. (2014). Distinguishing between incomplete lineage sorting and genomic introgressions: complete fixation of allospecific mitochondrial DNA in a sexually reproducing fish (Cobitis; Teleostei), despite clonal reproduction of hybrids. PLoS One 9: e80641. http://dx.doi.org/10.1371/journal. pone.0080641

De Gelas K, Janko K, Volckaert FAM, DE Charleroy D, et al. (2008). Development of nine polymorphic microsatellite loci in the spined loach, Cobitis taenia, and cross-species amplification in the related species C. elongatoides, C. taurica and C. tanaitica. Mol. Ecol. Resour. 8: 1001-1003. http://dx.doi.org/10.1111/j.1755-0998.2008.02135.x

Fujimoto T, Sakao S, Yamaha E and Arai K (2007). Evaluation of different doses of UV irradiation to loach eggs for genetic inactivation of the maternal genome. J. Exp. Zool. A Ecol. Genet. Physiol. 307: 449-462.

Glenn TC and Schable NA (2005). Isolating microsatellite DNA loci. Methods Enzymol. 395: 202-222. http://dx.doi. org/10.1016/S0076-6879(05)95013-1

Hamilton MB, Pincus EL, Di Fiore A and Fleischer RC (1999). Universal linker and ligation procedures for construction of genomic DNA libraries enriched for microsatellites. Biotechniques 27: 500-502, 504-507.

Janko K, Kotusz J, De Gelas K, Slechtová V, et al. (2012). Dynamic formation of asexual diploid and polyploid lineages: multilocus analysis of Cobitis reveals the mechanisms maintaining the diversity of clones. PLoS One 7: e45384. http://dx.doi.org/10.1371/journal.pone.0045384

Juchno D, Lackowska B, Boron A and Kilarski W (2010). DNA content of hepatocyte and erythrocyte nuclei of the spined loach (Cobitis taenia L.) and its polyploid forms. Fish Physiol. Biochem. 36: 523-529. http://dx.doi.org/10.1007/ s10695-009-9322-x

Kimizuka Y and Kobayashi H (1983). Geographic distribution of karyological races of Cobitis biwae (Cobitididae). Jpn. J. Ichthyol. 30: 308-312.

Kitagawa T, Watanabe M, Kitagawa E, Yoshioka M, et al. (2003). Phylogeography and the maternal origin of the tetraploid form of the Japanese spined loach, Cobitis biwae, revealed by mitochondrial DNA analysis. Ichthyol. Res. 50: 318 325. http://dx.doi.org/10.1007/s10228-003-0174-6

Kobayashi H (1976). Comparative study of karyo-types in the small and large races of spinous loaches (Cobitis biwae) (in Japanese with English abstract). Zool. Mag. 85: 84-87.

Kusunoki T, Arai K and Suzuki R (1994). Production of viable gynogens without chromosome duplication in spinous loach Cobitis biwae. Aquaculture 119: 11-23. http://dx.doi.org/10.1016/0044-8486(94)90440-5

Morishima K, Nakayama I and Arai K (2008). Genetic linkage map of the loach Misgurnus anguillicaudatus (Teleostei: Cobitidae). Genetica 132: 227-241. http://dx.doi.org/10.1007/s10709-007-9165-2

Saitoh K, Chen WJ and Mayden RL (2010). Extensive hybridization and tetrapolyploidy in spined loach fish. Mol. Phylogenet. Evol. 56: 1001-1010. http://dx.doi.org/10.1016/j.ympev.2010.04.021

Tóth G, Gáspári Z and Jurka J (2000). Microsatellites in different eukaryotic genomes: survey and analysis. Genome Res. 10: 967-981. http://dx.doi.org/10.1101/gr.10.7.967

Ueno K and Ojima Y (1976). Diploid-tetraploid complexes in the genus Cobitis (Cobitidae, Cyprinidae). P. Jpn. Acad. B 52: 446-449.

Genetics and Molecular Research 15 (3): gmr.15039027 
Van Puyvelde K, VAN Geert A and Triest L (2010). atetra, a new software program to analyse tetraploid microsatellite data: comparison with tetra and tetrasat. Mol. Ecol. Resour. 10: 331-334. http://dx.doi.org/10.1111/j.17550998.2009.02748.x

Vasil'ev VP, Vinogradov AE, Rozanov YM and Vasil'eva ED (1999). DNA content in cells of different forms from unisexual-bisexual complex of spined loaches from genus Cobitis and Luther's spined loach C. lutheri (Cobitidae). J. Ichthyol. 39: 377-383.

Zhang Q and Arai K (1996). Flow cytometry for DNA contents of somatic cells and spermatozoa in the progeny of natural tetraploid loach. Fish. Sci. 62: 870-877.

Genetics and Molecular Research 15 (3): gmr.15039027 